\title{
Formation of amphivasal vascular bundles in Dracaena draco stem in relation to rate of cambial activity
}

\author{
Joanna Jura-Morawiec ${ }^{1}$
}

Received: 25 February 2015/Revised: 14 May 2015/Accepted: 27 May 2015/Published online: 4 June 2015

(c) The Author(s) 2015. This article is published with open access at Springerlink.com

\begin{abstract}
Key message Two modes of amphivasal vascular bundle formation were identified, which may help determine the rate of radial growth in Dracaena draco stem.

Abstract Secondary growth of monocotyledonous plants results from monocot cambium activity. This lateral meristem gives rise to secondary tissues, i.e., secondary xylem and phloem arranged in vascular bundles, as well as the ground tissue that surrounds them. The aim of this study was to investigate the formation of vascular tissues relative to cambial activity in Dracaena draco stem. Based on the arrangement of mature amphivasal vascular bundles adjacent to the monocot cambium, regions differing in cambial activity were identified and sampled. Analysis carried out on transverse sections ( $3 \mu \mathrm{m}$ thick) revealed that rate of cambial activity influences the mode of vascular bundle formation and identified two distinct modes differing in terms of xylem (tracheid) differentiation. Strands of vascular parenchyma traversing the ring of tracheids within the amphivasal bundle are usually horizontally orientated. It is proposed, that owing to its location, the developing vascular bundle may function in phloem unloading before maturation of tracheids is completed. Dracaena draco is a promising object for investigating seasonal response of radial growth in monocot stems, the
\end{abstract}

Communicated by Y. Sano.

Joanna Jura-Morawiec

j.jura@gazeta.pl

1 Polish Academy of Sciences Botanical Garden-Centre for Biological Diversity Conservation in Powsin, Prawdziwka 2, 02-973 Warsaw, Poland modes of amphivasal vascular bundle formation being a helpful tool.

Keywords Monocot cambium - Seasonality - Secondary growth · Tracheids - Vascular bundle development

\section{Introduction}

The secondary growth of monocotyledonous plants is due to the activity of the monocot cambium. This meristem is made up of one type of initial consisting of fusiform, rectangular or polygonal cells, arranged in a non-storied pattern (Cheadle 1937; Philipson et al. 1971). These initials of the monocot cambium undergo periclinal divisions that lay down derivatives that subdivide and differentiate to form cells of the ground tissue (mainly centripetally), or to form cells of the vascular bundles (only centripetally). The arrangement of vascular tissues (i.e., phloem and the xylem) within the secondary vascular bundles tends to be species-specific. For example, in the stem of Yucca aloifolia (Barkley 1924) both collateral and amphivasal secondary bundles are present. By contrast, only amphivasal bundles occur in Dracaena marginata and D. draco (Scott and Brebner 1893), whereas only collateral bundles occur in Y. brevifolia (Carlquist 2012).

Our knowledge of secondary vascular bundle development in monocot stems is based mainly on the work of early anatomists. Two of these, namely, Scott and Brebner (1893) identified three sequential stages in bundle development: (1) regular rows of cambial derivatives, (2) slight disruption of this regular arrangement by the presence of long elements interspersed with short elements, and (3) further disturbances of regular rows by the presence of more elongate elements which enclose the short cells. 
Within each vascular bundle, the only elongated elements owing to intensive intrusive growth are xylem tracheids (Waterhouse 1987). The remaining cells of the vascular bundle (i.e., the sieve elements, companion cells and vascular parenchyma cells) do not grow intrusively, and thus, their length reflects that of the cambial initials (Röseler 1889; Cheadle 1937). Maturation of vascular bundle cells occurs in centrifugal sequence, i.e., cells on the inner (proximal) side of the vascular bundle mature first, whereas those on the outer (distal) part of the vascular bundle are still dividing and elongating (Tomlinson and Zimmermann 1969). In general, more xylem cells are produced than phloem cells, and the latter appear to differentiate and mature first (Barkley 1924; Stevenson 1980).

The secondary vascular bundles embedded in secondary, parenchymatous ground tissue constitute a peculiar type of "wood" (Tomlinson and Zimmermann 1967). Although it lacks growth rings corresponding to annual increments (Chamberlain 1921; Barkley 1924), its structure, nonetheless, can be the source of some useful information about how, in the past, various factors have affected the developmental processes in an individual arborescent monocot. For example, the eccentric secondary growth of a stem indicates a change in its position with respect to gravity. The monocot cambium usually produces more secondary tissues on the lower side of a leaning stem; however, growth eccentricity is not accompanied by the formation of reaction anatomy (Fisher 1975). Furthermore, the occurrence of "dark" and "light" rings in the secondary body reflects the periodic influence of factors that limit cambial activity. In those areas referred to as "dark" rings, the vascular bundles are smaller and more numerous per unit area, whereas the parenchyma cells are lignified, in contrast to the vascular bundles and parenchyma occurring in the "light" ring (Cheadle 1937). Factors such as low night temperatures, transplanting or insect infestations may affect the general vigour of the plant and also cause the ring-like appearance of secondary tissues (Fisher 1975).

In trees growing at temperate latitudes, the alternating active and dormant states of the vascular cambium causes a distinct annual ring structure with a characteristic early-/ latewood pattern. These patterns coincide with the cambial zone width, which, in turn, reflects the balance between the rate of cell differentiation and the rate of cell production (Wilson 1966). The monocot cambium is more or less active throughout the whole year; however, as was previously mentioned, some features of its derivatives (e.g., vascular bundle arrangement) may help identify areas having different growth rates. The formation of vascular bundles relative to monocot cambium activity has not previously been studied. My objective was to investigate amphivasal vascular bundle development in areas of the stem of $D$. draco differing in their rate of cambial activity.

\section{Materials and methods}

\section{Terminology}

The term 'cambial zone' relates here to the region extending from the last, outermost, radially arranged parenchyma cells as far as the cambial initials and their immediate innermost derivatives. The number of cell layers in the cambial zone and the number of not yet fully differentiated xylem elements (Fahn 1990) within a vascular bundle are taken as an indication of the rate of cambial activity. In vascular bundle development, the early and later stages were identified. The former stages involve only anticlinal (radial) and periclinal (tangential) division of the vascular bundle mother cells, whereas the latter refers to a variety of events specific to vascular bundle formation, with cell division being more or less complete, as well as growth of and/or secondary cell wall deposition in tracheids, and the differentiation of phloem and vascular parenchyma cells. The position of successive vascular elements during vascular bundle formation was recorded by reference to the centre of the axis (centrifugal, centripetal) or to an individual vascular bundle (distal, proximal).

\section{Material sampling and preparation}

The study was carried out on samples collected from stems of $D$. draco plants growing in the greenhouses of the Polish Academy of Sciences Botanical Garden-CBDC in Powsin, the Warsaw University Botanic Garden and in the breeding room of the Silesian Botanical Garden, Poland. All plants had vertical stems, with base diameters of 20, 24 and $4 \mathrm{~cm}$, respectively. Samples containing the monocot cambium and its derivative tissues (ca. $2 \mathrm{~cm}$ long, ca. $1 \mathrm{~cm}$ wide, ca. $1 \mathrm{~cm}$ thick) were excised from the basal part of the stem. Next, hand-cut, transverse sections of sampled tissues were prepared and examined under a stereoscopic microscope to identify the areas with the most compact/ widely spaced arrangement of vascular bundles adjacent to the monocot cambium. The two samples which differed most from each other in terms of bundle arrangement were selected for further, detailed study. The samples were subdivided into smaller blocks and, in sequence, embedded in Epon-resin, as described by Meek (1976), sectioned transversely at $3 \mu \mathrm{m}$ on a Tesla $490 \mathrm{~A}$ microtome, adhered to slides with Haupt adhesive, and stained using the Periodic Acid Schiff reaction (PAS) and toluidine blue. The resulting sections were examined using transmitted light 
and an OLYMPUS BX 41 microscope equipped with a camera Camedia C-3040. Transverse sections with fully matured secondary tissues adjacent to the cambial zone were used for measuring vascular bundles. The mean value is based on 50 measurements taken for each sample using an OptaView 7. Figures were assembled and prepared using CorelDraw Graphic Suite X5.

\section{Results and discussion}

\section{Amphivasal vascular bundle development with emphasis on tracheid differentiation}

The mode of vascular bundle formation differs depending on the activity of the monocot cambium. When the cambial zone becomes narrow and contains $2-3$ cells per radial file
(Fig. 1a), the rate of differentiation proceeds faster than that of division. The early stages of vascular bundle formation in D. draco (Fig. 1a-d) are much the same as in e.g., Aloe pleuridens or A. ferox (Chamberlain 1921). Usually more than one row of cambial derivatives contribute to the formation of a single bundle (Fig. 1b). During the later stages of vascular bundle formation, characteristic zonation (division into zones) of the vascular bundle is visible, defined by the location of groups of tracheids in subsequent more advanced phases of differentiation i.e., cell division, cell growth (radial, longitudinal) and cell maturation (thickening and lignification). For instance, a developing amphivasal vascular bundle may contain a zone of mature tracheids on its inner (proximal) side, while on its outer (distal) side, cells are still dividing (Fig. 1e) and/or are at the growth stage (Fig. 1f). When the cambial zone becomes wide (i.e., 5-6 celled), the process of division is

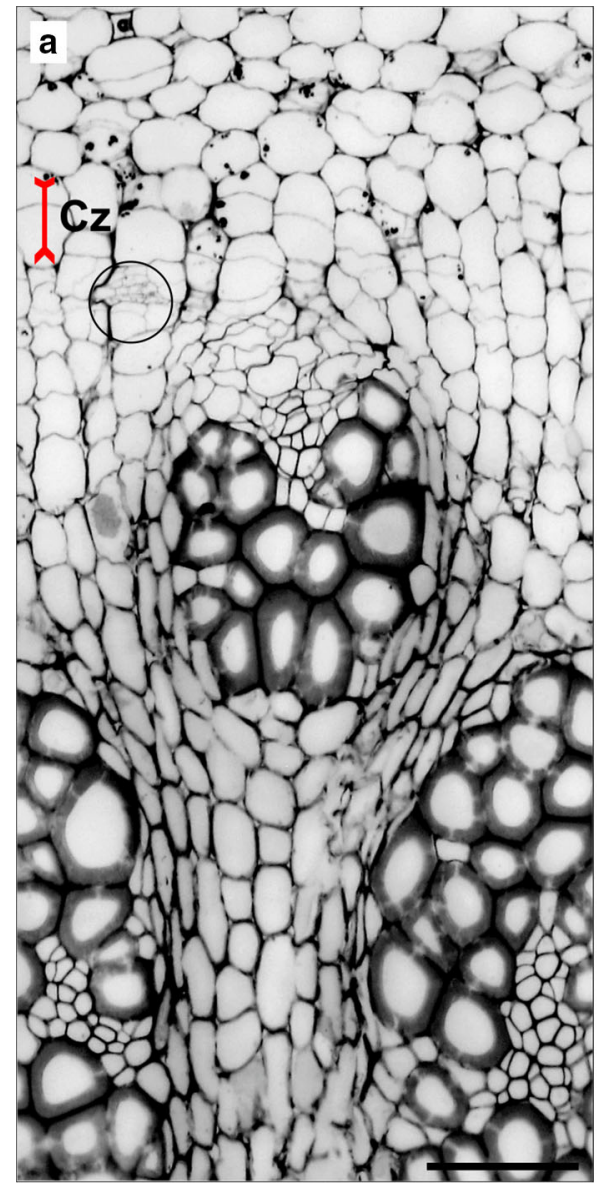

Fig. 1 Details of amphivasal secondary vascular bundle formation in D. draco stem during low cell division activity of the monocot cambium (when the rate of cell division is slower than the rate of differentiation). a General view of the cambial zone $(C z$, marked with a red line) and associated tissues i.e., outer cortex cells and inner secondary vascular bundles embedded in ground tissue; a circle indicates the area of origin of a new bundle. b-d Representative

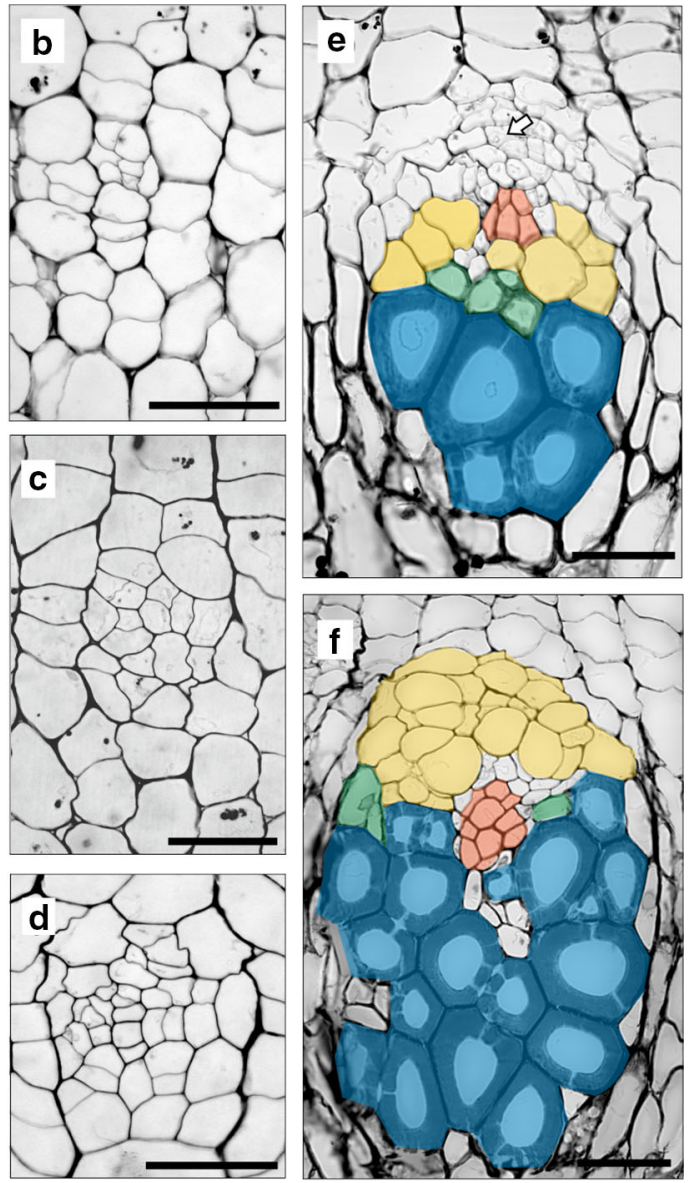

sections of the successive early stages of vascular bundle development. e, f Later developmental stages with characteristic zonation; the zone of division of the vascular bundle mother cells (arrow); the zone of tracheid growth (yellow); the zone of tracheid maturation (green); the zone of mature tracheids (blue); sieve elements with companion cells (orange). Scale bar $=100 \mu \mathrm{m} ; \mathbf{b}-\mathbf{f}=50 \mu \mathrm{m}$ 


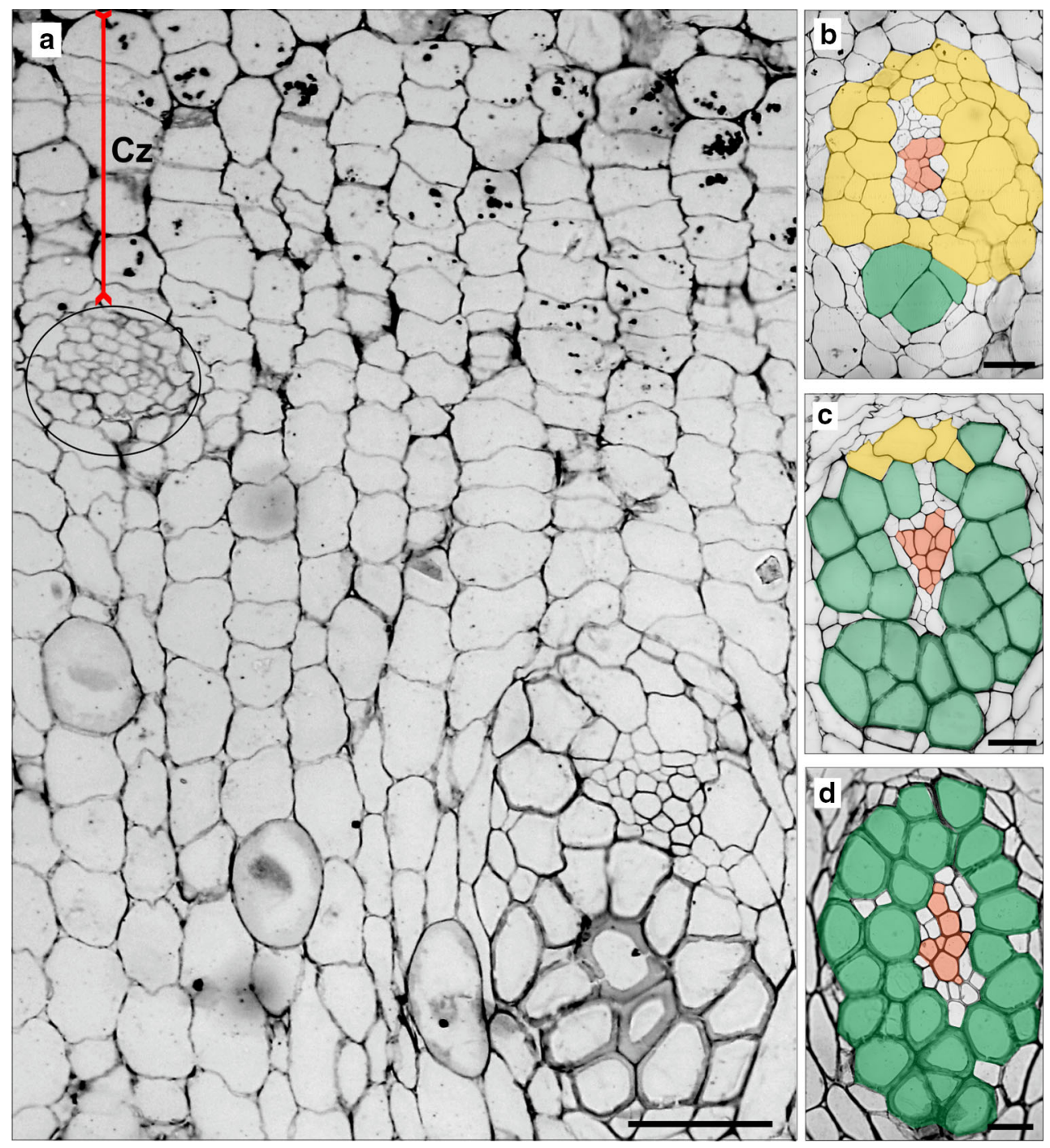

Fig. 2 Details of amphivasal secondary bundle formation in $D$. draco stem during high activity of the monocot cambium (when division proceeds faster than differentiation). a General view of the cambial zone $(\mathrm{Cz})$ and associated tissues, details as described in Fig. 1a. b-d
Representative sections of the successive, later stages of vascular bundle development. Colour descriptions as in Fig. 1. Scale bar $\mathbf{a}=100 \mu \mathrm{m} ; \mathbf{b}-\mathbf{d}=50 \mu \mathrm{m}$

its differentiation (Figs. 1f, 2d). In general, phloem differentiates before xylem (Esau 1965). This pattern follows the evolutionary development of these tissues in early plants. The sieve elements and the companion cells of the investigated species are easy to identify, in contrast to those species such as A. ferox, where vascular bundles contain scanty phloem (Chamberlain 1921). The ratio of the size of companion cells (which are much smaller) to sieve elements indicates that the phloem strand has differentiated for unloading assimilates (van Bel 1996). However, it is known that in view of source-sink relationships (Foyer and Paul 2001), the activity of secondary parenchyma cells in arborescent plants is particularly relevant (reviewed by Spicer 2014; Carlquist 2015). It has been proposed recently that vascular parenchyma cells 


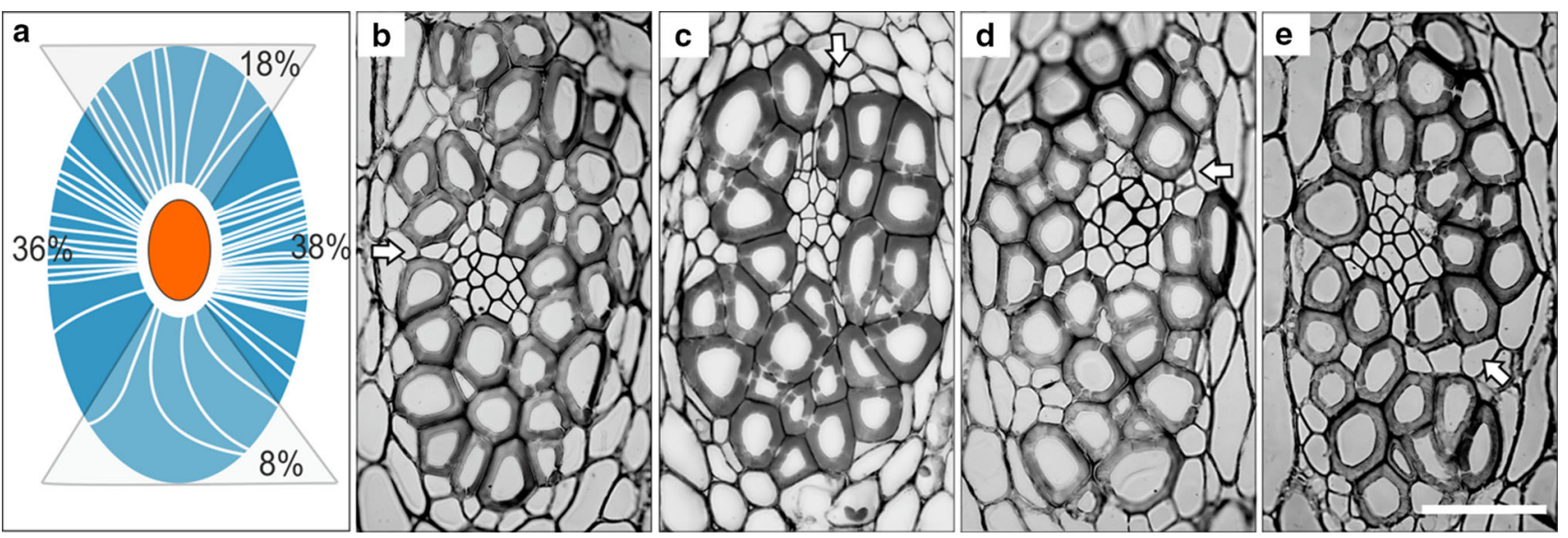

Fig. 3 Distribution of vascular parenchyma cells traversing the ring of tracheids in the mature amphivasal secondary bundles of $D$. draco stem. a Schematic representation obtained by superimposing 50 amphivasal vascular bundles according to their position relative to the monocot cambium. The monocot cambium (not shown) would be at the top of the scheme. Tracheids (blue) encircle the phloem (orange); a single, white line indicates the position of the vascular parenchyma strand in a given bundle. The percentages indicate the frequency of vascular parenchyma strand occurrence in four vascular bundle areas. b-d Selected examples of vascular bundles with vascular parenchyma cells traversing the ring of tracheids (arrow). Scale bar $=100 \mu \mathrm{m}$

lignification of ground tissue increases the further these parenchyma cells are from the meristem, (4) the rate of cambial activity determines the size of mature vascular bundles and their arrangement in the secondary plant body. The first mode (Fig. 4a) corresponds with bundle formation within the so-called "dark" ring. Here, the cambial zone is narrow and gives rise to small vascular bundles that are compactly arranged, in contrast to those of the "light" ring. A wider cambial zone initiates vascular bundle formation resulting in the formation of loosely arranged amphivasal vascular bundles (Fig. 4b).

It is worth emphasizing that low cambial activity is not always accompanied by a reduction in vascular bundle size. The result of an experiment on the leaning/horizontal stems of some species of the genera Dracaena and Beaucarnea (Fisher 1975) showed the presence of smaller vascular bundles on the upper side of $B$. recurvata and $D$. reflexa stems, but larger vascular bundles in $D$. fragrans. In $D$. draco, the mean bundle radial/tangential diameter was $305.4( \pm 38.0) / 183.2( \pm 18.1) \quad \mu \mathrm{m}$ and $404.4 \quad( \pm 25.6) /$ $219.6( \pm 22.9) \mu \mathrm{m}$, respectively, for low and high rates of monocot cambial activity. These measurements relate to tissues sampled from vertical stems differing in age, and therefore, investigation of a direct relationship between vascular bundle size and cambial activity was not possible. Cambial activity, and thus, vascular bundle size are under hormonal control. The cambium is induced and controlled by gradients of auxin, gibberellin and cytokinin, whereas early phloem differentiation is induced only by low auxin concentration. Later, tracheid differentiation is induced by gradients of higher concentrations of auxin, in conjunction with gibberellin stimulation (Aloni 2015). 
a

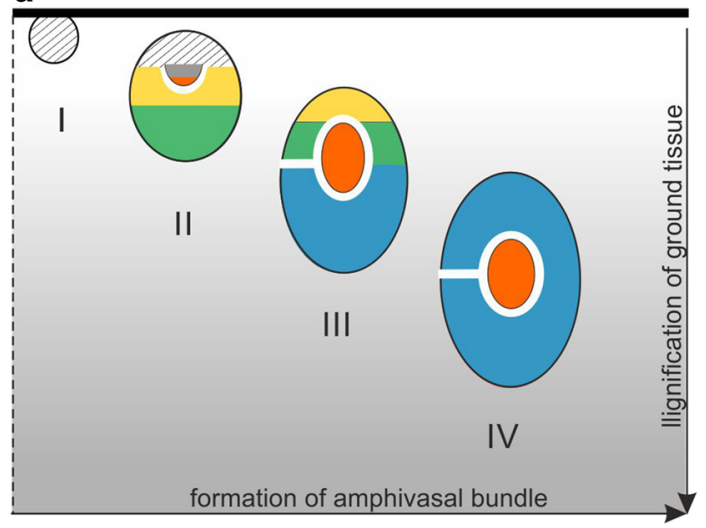

b

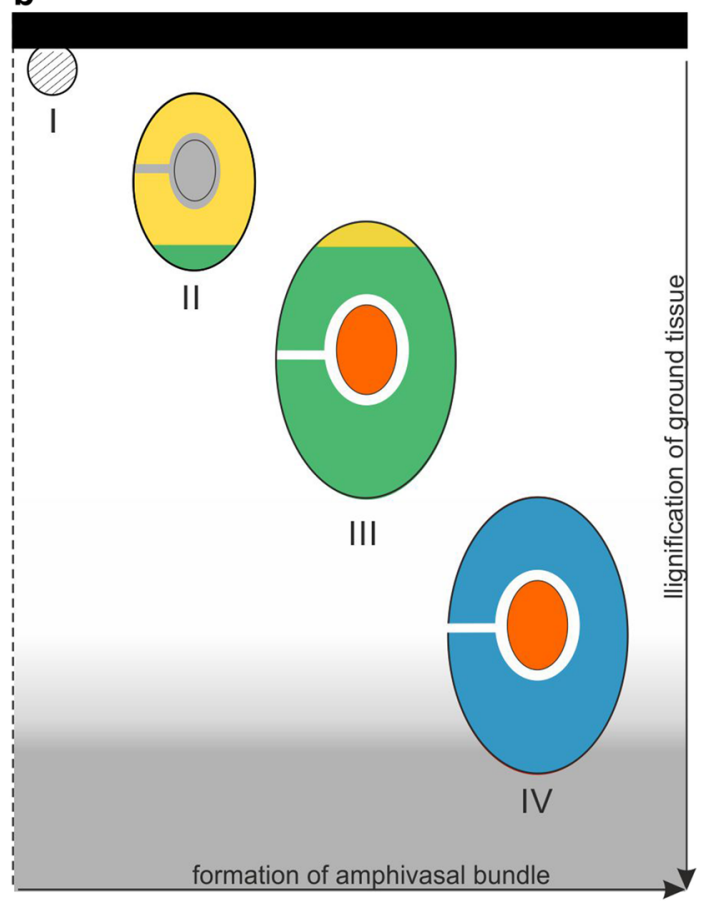

Key:

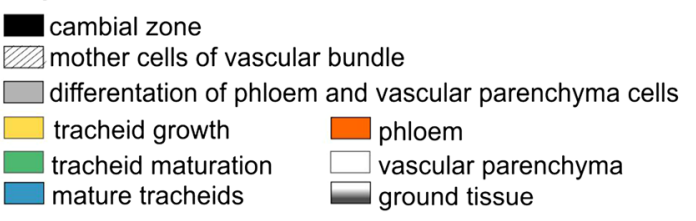

Fig. 4 Mode of amphivasal vascular bundle formation in transverse view. a Low rate of cambial activity. b High rate of cambial activity. (I-IV) Subsequent stages of vascular bundle development with position-related structural changes colour coded. For more information, see text

The investigated plants of $D$. draco were grown in greenhouses at a relatively uniform temperature and water supply conditions. Nevertheless, it is possible that other internal and external factors or, indeed, interaction between them, may affect monocot cambium activity, including growth regulators, age or vigour of the plant, or photoperiod (Fisher 1973, 1975; Fisher et al. 1974; Symon 1974). The main point is that it would be difficult to quantify experimentally the effects of a single factor on cambial activity and vascular bundle formation, but it is not impossible.

Early plant anatomists attempted to correlate differences in the activity of the monocot cambium of plants growing in their natural habitats with environmental changes, but with little success e.g., correlations of cambial activity with rainfall in the arborescent subtropical desert species $A$. dichotoma (Lindinger 1909) and A. ferox (Chamberlain 1921). Perhaps these plants were not suitable objects for such studies, since, according to Chamberlain (1921), "the difference between dry and wet seasons was not so marked". Monocot cambium activity in the stems of $D$. draco plants growing in their natural habitat, including the Canary Islands and the western part of Morocco (Marrero et al. 1998), has not been studied to date. In these areas, the frequency of fog plays an important role in maintaining vegetation. It would be interesting to know whether the structure of secondary tissues of $D$. draco growing in these two natural habitats reflects seasonal changes to the environment, especially in the context of recent climatic data provided by Marzol et al. (2011). These authors demonstrated the occurrence of inverse seasonality, "since fog water is collected in Morocco during the winter (the Moroccan pattern), whereas on the Canary Islands, this happens in the summer (the Canary pattern)". In view of these findings, $D$. draco appears to be a promising object for investigating the seasonal response of radial growth in monocots. The recognized modes of amphivasal bundle formation provide a helpful tool enabling (without causing any serious damage to the plant) determination and comparison of the rate of radial growth of the stem of $D$. draco during the growing season, as influenced by Moroccan and Canary patterns.

Author contribution statement J. J-M Study conception and design, acquisition of data, analysis and interpretation of data, writing of the manuscript.

Acknowledgments The author wishes to thank Prof. Wiesław Włoch for helpful discussions and Mrs. Joanna Bogdanowicz for assistance during sample collection at Warsaw University Botanic Garden.

Conflict of interest The author declares that there is no conflict of interest.

Open Access This article is distributed under the terms of the Creative Commons Attribution 4.0 International License (http:// creativecommons.org/licenses/by/4.0/), which permits unrestricted use, distribution, and reproduction in any medium, provided you give appropriate credit to the original author(s) and the source, provide a link to the Creative Commons license, and indicate if changes were made. 


\section{References}

Aloni R (2015) Ecophysiological implications of vascular differentiation and plant evolution. Trees 29:1-16

Barkley G (1924) Secondary stellar structure of Yисса. Bot Gaz 78:433-439

Carlquist S (2012) Monocot xylem revisited: new information, new paradigms. Bot Rev 78:87-153

Carlquist S (2015) Living cells in wood. 1. Absence, scarcity and histology of axial parenchyma as keys to function. Bot J Linn Soc 177:291-321

Chamberlain C (1921) Growth rings in monocotyledons. Bot Gaz 72:293-304

Cheadle VI (1937) Secondary growth by means of a thickening ring in certain monocotyledons. Bot Gaz 98:535-555

Esau K (1965) Plant anatomy. John Wiley and Sons, New York

Fahn A (1990) Plant anatomy. Pergamon Press, Oxford

Fisher JB (1973) The monocotyledons: their evolution and comparative biology II. Control of growth and development on the monocotyledons-new areas of experimental research. Q Rev Biol 48:291-298

Fisher JB (1975) Eccentric secondary growth in Cordyline and other Agavaceae (Monocotyledonae) and its correlation with auxin distribution. Am J Bot 62:292-302

Fisher JB, Burg SP, Kang BG (1974) Relationship of auxin transport to branch dimorphism in Cordyline, a woody monocotyledon. Physiol Plant 31:284-287

Foyer CHH, Paul MJ (2001) Source-sink relationships. Wiley, Chichester

Jura-Morawiec J, Wiland-Szymańska J (2014) A novel insight into the structure of amphivasal secondary bundles on the example of Dracaena draco L. stem. Trees 28:871-877

Lindinger L (1909) Die struktur von Aloë dichotoma L., mit anschliessenden allgemeinen betrachtungen. Beih Bot Centralbl 24:211-253

Marrero A, Almeida RS, Gonzalez-Martin M (1998) A new species of the wild dragon tree, Dracaena (Dracaenaceae) from Gran
Canaria and its taxonomic and biogeographic implications. Bot J Linn Soc 128:291-314

Marzol MV, Sánchez Megia JL, Yanes A (2011) Meteorological patterns and fog water collection in Morocco and the Canary Islands. Erdkunde 65:291-303

Meek GA (1976) Practical electron microscopy for biologists. John Wiley and Sons, London New York, Sydney, Toronto

Philipson WR, Ward JM, Butterfield BG (1971) The vascular cambium: its development and activity. Chapman and Hall Ltd., London

Röseler P (1889) Das Dickenwachsthum und die Entwicklungsgeschichte der secundären Gefässbündel bei den baumartigen Lilien. Pringsh Jahr f Wiss Bot 20:292-348

Scott DH, Brebner G (1893) On the secondary tissues in certain monocotyledons. Ann Bot 7:22-62

Spicer R (2014) Symplasmic networks in secondary vascular tissues: parenchyma distribution and activity supporting long-distance transport. J Exp Bot 65:1829-1848

Stevenson DW (1980) Radial growth in Beaucarnea recurvata. Am J Bot 67:476-489

Symon ED (1974) The growth of Dracaena draco-dragon's blood tree. J Arnold Arbor 55:51-58

Tomlinson PB, Zimmermann MH (1967) The "wood" of monocotyledons. IAWA Bull 2:4-24

Tomlinson PB, Zimmermann MH (1969) Vascular anatomy of monocotyledons with secondary growth-an introduction. J Arnold Arbor 50:159-179

van Bel AJE (1996) Interaction between sieve element and companion cell and the consequences for photoassimilate distribution. Two structural hardware frames with associated physiological software packages in dicotyledons? J Exp Bot 47:1129-1140

Waterhouse JT (1987) The phylogenetic significance of Dracaenatype growth. Proc Linn Soc New South Wales 109:129-138

Wilson BF (1966) Mitotic activity in the cambial zone of Pinus strobus. Am J Bot 53:364-372 